DOI 10.22460/infinity.v7i1.p25-34

\title{
ANALYSIS OF STUDENTS' MATHEMATICAL ABSTRACTION ABILITY BY USING DISCURSIVE APPROACH INTEGRATED PEER INSTRUCTION OF STRUCTURE ALGEBRA II
}

\author{
Elsa Komala \\ Universitas Suryakancana, Jl. Pasir Gede Raya, Bojongherang, Cianjur, West Java, Indonesia \\ elsakomala@gmail.com
}

Received: August 06, 2017 ; Accepted: August 24, 2017

\begin{abstract}
This research is subject to describe students' mathematical abstraction ability using the discursive approach of peer instruction integration, to get an idea about the problems faced by students and to study about the interventions needed by students to overcome the problems. This research using the quantitative descriptive approach with pre-experimental design: the one-shot case study design, which is done to the students in the course of the structure of algebra II. Based on the data analysis, result of the research shows that ability of students' mathematical abstraction using the discursive approach of peer instruction integration in the course of the structure of algebra II does not exceed $85 \%$ of ideal criteria determined. Obstacles faced by students such as cognitive obstacles, genetic and psychological obstacles, didactic obstacles, epistemological obstacles. Interventions that need to be given such as by providing reinforcement to the mastery of prerequisite material, conditioning through drill, practice, and exercise, providing scaffolding, raises students awareness of what they learn, convergent interventions in the form of a closed-ended investigative question.
\end{abstract}

Keywords: Mathematical Abstraction, Discursive Approach, Peer Instruction

\begin{abstract}
Abstrak
Tujuan penelitian ini untuk mendeskripsikan kemampuan abstraksi matematis mahasiswa menggunakan pendekatan diskursif integrasi peer instruction, memperoleh gambaran tentang permasalahan yang dihadapi mahasiswa dan mengkaji tentang intervensi-intervensi yang diperlukan mahasiswa guna mengatasi permasalahannya. Penelitian ini menggunakan pendekatan deskriptif kuantitatif dengan desain pre experimental: the one-shot case study design, terhadap mahasiswa pada mata kuliah struktur aljabar II. Berdasarkan analisis data, menunjukkan bahwa kemampuan abstraksi matematis mahasiswa menggunakan pendekatan diskursif integrasi peer instruction pada mata kuliah struktur aljabar II tidak melebihi 85\% dari kriteria ideal yang ditetapkan. Hambatan mahasiswa dalam melakukan abstraksi matematis diantaranya hambatan kognitif, hambatan genetis dan psikologis, hambatan didaktis, hambatan epistemologi. Intervensi-intervensi yang perlu diberikan kepada mahasiswa guna mengatasi permasalahan tersebut diantaranya dengan memberikan penguatan terhadap penguasaan materi pra syarat, melakukan pembiasaan melalui kegiatan drill, practice, dan exercise, memberikan scaffolding, memunculkan kesadaran pada diri mahasiswa mengenai apa yang dipelajarinya, intervensi konvergen berupa pemberikan pertanyaan investigasi yang bersifat tertutup.
\end{abstract}

Kata Kunci: Abstraksi Matematis, Pendekatan Diskursif, Peer Instruction.

How to Cite: Komala, E. (2018). Analysis of Students' Mathematical Abstraction Ability by using Discursive Approach Integrated Peer Instruction of Structure Algebra II. Infinity, 7 (1), 25-34 doi:10.22460/infinity.v7i1.p25-34 


\section{INTRODUCTION}

For the college level, the mathematical material is increasingly difficult to learn. Artigue (1998) argue that mathematics learning is often rated negatively by students and they have considerable difficulty with some mathematical processes such as reasoning, non-routine problem solving and proving. According to Tall (2008), the change from elementary thinking to advanced mathematical thinking involves a significant transition, is from describing to defining, from convincing to proofing logically based on a definition. The transition process is a problem for students Herlina (2015).

The purpose of education in Indonesia requires that students, especially prospective teachers are required to have multi-ability, one of the skills that need to be mastered in mathematics is the ability of abstraction. According to Nurhasanah, Kusumah, \& Sabandar (2017) learning mathematics is a complicated process because the objects in it are so abstract, therefore the mathematical concept can not be transferred to the students directly (directly convey the general form which seems like a piece of information), but it must give through a process so that learning will feel more meaningful and lasting, the process is called the process of abstraction of a concept. besides, Nurhasanah et al (2017) also expressed that the essence of mathematics is an abstraction and abstract concept. Therefore, students need advanced mathematical thinking. One of the subjects that require advanced mathematical thinking is the Structure of Algebra I and II. In addition, when students are asked to explain the results of their calculations, they experience confusion in representing and abstracting it.

Often we see and hear the expression about the number of students whose activities are less thinking. They only learn but their way of learning is limited to hearing the information of his lecturer then not trying to understand the material being taught. Especially on courses such as Structure Algebra I and II. The course of Structure of Algebra II (Ring Theory) is a continuation course of the Structure of Algebra I (Group Theory) which has introduced a structural mathematical concept in general that has been discovered or studied previously. Based on observations in the field when the course Structure of Algebra the generalization process of the basic concept was not all students are able to master it.

The same thing also express by Nurlaelah \& Sumarmo (2009) that the course of algebra structure is a subject that contains abstract concepts because the nature of the course is like that then students often have difficulty in learning it. How to introduce the concept with the announcement of the previous concept can be said process of abstraction. Building mathematical concepts independently by students is fundamental to mathematics learning. Students are given the widest opportunity to build and construct his own knowledge. Because the process of abstraction is the way of the emergence of a concept, meaning it is very important in learning mathematics, so the ability of mathematical abstraction becomes a capability that must be owned by students to study the course of algebraic structure. According to Tall (2008) that abstraction is the process of describing a particular situation to the realm of a concept that can be thought (thinkable concept) through a construction. Such thoughtful concepts can then be used at more complex and complex thinking levels. According to him, the process of abstraction can occur in some circumstances, but there are three circumstances that usually bring up the process of abstraction in the process of learning mathematics. The first state can arise when the individual focuses his attention on the characteristics of the objects he or she observes, then gives the name through a process of classifying by category into several groups. 
Problems that arise in learning Structure Algebra II is usually, students difficult to perform an empirical abstraction for example students have difficulty imagining the properties of objects or even generalized numbers because the learning experience is not the same. This can lead to weak visualization of previous concepts so that students feel difficulty when understanding the new concept. Likewise difficulties occur in theoretical abstraction, because the experience of learning and the process of illustration of real objects is not used as a reference, but based on previous theories. This creates an obstacle if previous concepts lack understanding which results in the formation of a new concept of theoretical abstraction. This is a challenge for lecturers to solve the problem. One possible solution is to use a particular learning approach. So based on the experience of previous lecture lesson that is Structure Algebra I, which is the prerequisite course for taking the course of Structure Algebra II when the student exam only reveals the material they have memorized it, without being able and understand in doing the abstraction both empirical and theoretical.

One of the learning that has potential to develop student activeness and able to improve abstraction ability in learning is discursive approach of peer instruction integration. The discursive approach focuses on communication in the form of debates, logical reasons in writing, and mathematical communication so that this approach views students in the classroom as learning societies that interact with each other.

In peer instruction is interspersed with concept questions (Crouch \& Mazur, 2001) and involves student activeness in learning (Fagen, Crouch, \& Mazur, 2002). Students are given the opportunity to think in solving the conceptual question, then discuss with their peers. In addition, in learning is expected to optimize the concept ability through thinking and discussing with colleagues. Accordingly, peer instruction lessons are more effective than classroom discussions (Nicol, \& Boyle, 2003). A rich learning environment with peer discussions can develop critical thinking skills and deep mastery of concepts in students (Anderson, Howe, Soden, Halliday, \& Low, 2001).

Based on the background that has been described previously, then the formulation of this research problem is to know: 1) How the ability of mathematical abstraction of students using discursive approach of peer instruction integration in the course of Structure Algebra II; 2) What problems faced by students in solving the problem of mathematical abstraction in the course of Structure Algebra II; And 3) What interventions should be given to the students to overcome the problems faced in solving the mathematical abstraction problem in the course of Structure Algebra II.

\begin{abstract}
Ability of Mathematical Abstraction
The ability of mathematical abstraction is the ability of thinking that connects mathematical concepts into new concepts with the generalization process. According to Piaget (Bermejo \& Diaz, 2007), abstraction is divided into 2 types, namely empirical abstraction and reflective abstraction. While Mitchelmore \& White (2007) distinguish abstractions into empirical abstractions and theoretical abstractions.
\end{abstract}

\title{
Peer Instruction
}

Peer instruction is a lesson interspersed with short conceptual questions designed to express misunderstandings and to engage students to be active in learning. 


\section{Discursive Approach}

One approach to learning which views language, communication, discourse, and thinking is not a separate object of theoretical reflection is a discursive approach. So in education, this discursive approach has the intention to use essay writing, discussion and debate communication forum in the field of mathematics in the classroom.

\section{METHOD}

This research uses the quantitative descriptive approach with the experimental method. The experimental design used in this research is pre-experimental design type one-shot case study. In this design, there is a group treated (treatment), and then observed the results.

Treatment in this research is a discursive approach to peer instruction integration, as well as an independent variable in research. Meanwhile, the results observed in this study are students' mathematical abstraction abilities, which is also a dependent variable in the study. The research paradigm is described as follows:

$$
\mathrm{X} \quad \mathrm{O}
$$

Information:

$\mathrm{X}=$ Discursive approach of peer instruction integration

$\mathrm{O}=$ Ability of mathematical abstraction

\section{RESULTS AND DISCUSSION}

\section{Description of Learning with Discusive Approach Peer Instruction Integration}

Table 1. Learning Phase with Discursive Approach Peer Instruction Integration

\begin{tabular}{|c|c|c|}
\hline \multirow{2}{*}{ Phase } & \multicolumn{2}{|c|}{ Learning Activities } \\
\hline & Lectur & Student \\
\hline $\begin{array}{l}\text { Problem orientation in } \\
\text { peer }\end{array}$ & $\begin{array}{l}\text { a. The lecturer raises the } \\
\text { problem through Student } \\
\text { Worksheet done by the } \\
\text { student } \\
\text { b. The lecturer proposes a } \\
\text { conceptual test that relates } \\
\text { to the learning material } \\
\text { presented }\end{array}$ & $\begin{array}{l}\text { a. Together with his group's } \\
\text { friends, the students ask the } \\
\text { concept questions (peer } \\
\text { instruction) which will only } \\
\text { be answered "yes" and "no" } \\
\text { by the lecturer. } \\
\text { b. Students formulate the issue } \\
\text { ses-uai with the material } \\
\text { being studied }\end{array}$ \\
\hline $\begin{array}{l}\text { hypothesized in peer } \\
\text { (discussion) }\end{array}$ & $\begin{array}{l}\text { Lecturer guides students to } \\
\text { make hypothesis } \\
\text { completion }\end{array}$ & $\begin{array}{l}\text { a. Students individually think } \\
\text { for answers to the given } \\
\text { concept tests that are in the } \\
\text { Student Worksheet. } \\
\text { b. Together with his student } \\
\text { group the students } \\
\text { hypothesized the problems } \\
\text { that would later be } \\
\text { commented on by other } \\
\text { groups }\end{array}$ \\
\hline
\end{tabular}




\begin{tabular}{|c|c|c|}
\hline \multirow{3}{*}{$\begin{array}{l}\text { Phase } \\
\text { test the hypothesis in } \\
\text { peer (essay writing) }\end{array}$} & \multicolumn{2}{|c|}{ Learning Activities } \\
\hline & Lectur & Student \\
\hline & $\begin{array}{l}\text { a. Lecturers guide students } \\
\text { to experiment to test } \\
\text { their hypotheses. } \\
\text { b. Lecturer guides students } \\
\text { in analyzing data }\end{array}$ & $\begin{array}{l}\text { a. Students } \\
\text { experiments in accordance } \\
\text { with the Student Worksheet. } \\
\text { b. Students conduct, observe } \\
\text { and record carefully the } \\
\text { results of discussions that } \\
\text { have been made with his } \\
\text { group friends. } \\
\text { c. Students analyze thought- } \\
\text { provoking data and discuss } \\
\text { the hypotheses they make } \\
\text { with their group mates. } \\
\text { d. Students also discuss the } \\
\text { answers to the mathematical } \\
\text { abstraction concept test given } \\
\text { at the beginning with their } \\
\text { group mates }\end{array}$ \\
\hline $\begin{array}{l}\text { Presentation of data in } \\
\text { peer (communication } \\
\text { forum) }\end{array}$ & $\begin{array}{l}\text { The lecturer guides the } \\
\text { students to present the results }\end{array}$ & $\begin{array}{l}\text { a. The students presented the } \\
\text { results, which were then } \\
\text { responded by other groups. } \\
\text { b. Conveys the concept test } \\
\text { answers (mathematical } \\
\text { abstraction abilities) provided } \\
\text { at the beginning of the lesson }\end{array}$ \\
\hline $\begin{array}{l}\text { Feedback } \\
\text { (Discussion) }\end{array}$ & $\begin{array}{l}\text { a. The lecturer provides } \\
\text { reinforcement of the } \\
\text { results as well as } \\
\text { provides confirmation } \\
\text { of the concept test } \\
\text { (mathematical } \\
\text { abstraction abilities) } \\
\text { given at the } \\
\text { beginning. } \\
\text { b. The lecturer gives an } \\
\text { example of the } \\
\text { problem. } \\
\text { c. Lecturers provide } \\
\text { evaluation questions }\end{array}$ & $\begin{array}{l}\text { a. Students pay attention to the } \\
\text { strengthening of the lecturers } \\
\text { as well as to revise the } \\
\text { concept test results } \\
\text { (mathematical abstraction } \\
\text { abilities) that have been done } \\
\text { at the beginning of the } \\
\text { lesson. } \\
\text { b. Students pay attention to } \\
\text { lecturers. } \\
\text { c. Students work on evaluation } \\
\text { questions. }\end{array}$ \\
\hline Peer conclusion & $\begin{array}{l}\text { Evaluating the conclusions } \\
\text { and the results of discussions } \\
\text { that have been made by the } \\
\text { students in accordance with } \\
\text { the material presented }\end{array}$ & $\begin{array}{l}\text { ogether with his student friends } \\
\text { the students made a conclusion of } \\
\text { the results, then expressed in the } \\
\text { class and responded to other } \\
\text { groups }\end{array}$ \\
\hline
\end{tabular}




\section{Description of Data Ability Mathematical Ability}

Based on the results of data analysis abstract mathematical abilities obtained from the test instrument in the form of a set of midterm exam and final exam problems using the $\mathrm{z}$ test for one sample, obtained the value of $Z$ score $=-5.715$ and the critical $Z$ value $=-1,645$. In the right-handed testing criterion, the value of $\mathrm{Z}$ score is in the reception area $\mathrm{H}_{0}$ because $\mathrm{Z}$ score $<\mathrm{Z}$ critical so that $\mathrm{H}_{0}$ is received (not enough evidence to reject $\mathrm{H}_{0}$ ). This shows that at $95 \%$ confidence level there is not enough evidence to suggest that students' mathematical proofing ability using the discursive approach of peer instruction integration in the course of structure algebra II significantly exceeds $85 \%$ of ideal criteria. In other words, the data obtained is not sufficient to prove that the proposed research hypothesis is true.

The description of the data on midterm exam and final exam values indicates an increase in the value obtained by students during midterm exam and final exam. The average increase is 0.14 or is in a low category. In other words, although the students' mathematical abstraction ability has not reached $85 \%$ of the ideal criteria set, but by using the discursive approach the integration of peer instruction abstraction ability develops quite well from time to time, so that if this approach is continuously applied and developed then abstraction ability Mathematical students can continue to grow.

Description of the achievement of students' mathematical abstraction abilities based on measured ability indicators that are 1) Abstraction reflective, in the form of integration and problem formulation and problem transformation into symbol form; 2) The empirical abstraction, ie making generalizations, the formation of mathematical concepts related to other concepts, the formation of further mathematical objects and the formalization of mathematical objects; and 3) Theoretical abstraction, the process of manipulating symbols.

Table 2. Percentage of Mathematical Ability Achievement Ability

\begin{tabular}{lcc}
\hline \multicolumn{1}{c}{ Indicator } & Percentage (\%) & Information \\
\hline $\begin{array}{l}\text { Indicator 1 (reflective abstraction): } \\
\text { Integrate and problem formulation and problem }\end{array}$ & 38.9 & Almost Half \\
transformation into symbol form & & \\
\hline Indicator 2 (empirical abstractions): & 65.7 & Mostly \\
To generalize, the formation of mathematical concepts & & \\
related to other concepts, the formation of further & & \\
mathematical objects and the formalization of & & Nearly Half \\
mathematical objects & 33.2 & \\
\hline Indicator 3 (theoretical abstraction): & & \\
Able to manipulate symbols &
\end{tabular}

Based on the data from Table 2. it is known that from 35 students, in indicator 1 almost half (38.9\%) students have been able to integrate and problem formulation and problem transformation into symbol form (reflective abstraction), indicator 2 mostly (65.7\%) Has been able to generalize, the formation of mathematical concepts related to other concepts, the formation of further mathematical objects and the formalization of mathematical objects (empirical abstractions). Nearly half (33.3\%) in indicator 3 students have been able to manipulate symbols (theoretical abstraction). This shows an increase in the percentage of mathematical abstraction ability achievement from the previous year. However, the abilities 
of mathematical abstraction still need to be developed and improved especially on the first and third indicators relating to performing reflective abstractions and theoretical abstractions.

\section{Description of Mathematical Abstraction Problems}

Data about problems faced by students in performing mathematical abstraction obtained from the answer sheet of midterm exam and final exam workmanship that is then processed and analyzed descriptively and reinforced with an open questionnaire that is filled after the work on final exam. Descriptive analysis is done by describing or describing the data that has been collected as it is without intending to make generalizations. The process of data analysis is done by categorizing errors of student mathematical proofing based on similar errors and making the percentage of answers in each category called obstacles. In general there are four categories of problems faced by students in performing mathematical abstractions which are called obstacles in the course of algebra structure II that is the problem is in line with the opinion of Tall (2008): 1) Cognitive obstacles, occurs when students have difficulty in learning; 2) Genetic and psychological obstacles, occurring as a result of a student's personal development; 3) Didactic obstacles, due to the teacher's teaching nature; 4) The epistemological obstacles, occurs because of the nature of the mathematical concept itself.

Table 3. Percentage of Obstacles in Mathematical Abstraction

\begin{tabular}{lcc}
\hline \multicolumn{1}{c}{ Obstacles } & Percentage (\%) & Information \\
\hline Cognitive & 77.1 & Most \\
Genetic and psychological & 25.7 & Almost Half \\
Didactic & 51.4 & Most \\
Epistemological & 65.7 & Most \\
\hline
\end{tabular}

By the Table. 3 found that from 35 students, most of them (77.1\%) students experience cognitive obstacles, almost half $(25.7 \%)$ students experience genetic and psychological obstacles, most (51.4\%) of students have didactic obstacles, and Most (65.7\%) students experience epistemological obstacles. The data shows that the problems and obstacles faced by students in performing mathematical abstractions in the course of structure algebra II are very complex so that some interventions given by the lecturers to the students are needed to overcome the problem.

\section{Interventions to be Assumed in Course Structure Algebra II}

After knowing the problems faced by students in doing mathematical abstraction in the course of the structure algebra II, the researchers tried to formulate the interventions that need to be given to overcome the problems faced by students in doing mathematical abstraction in the course of structure algebra II. The formulation of these interventions is based on the research conducted by the researcher on the problems that occur based on the perspective of learning theory that has been formulated by experts who adapted to the characteristics of the ability and habits of student learning and thinking.

Based on the result of the research done, the researcher resulted from the suspicion that the problems that occur in relation to students' mathematical abstraction ability are caused by 1) the lack of mastery of pre-condition materials such as group theory, set, number system, binary operation characteristics, 2) lack of exercise intensity in mathematical abstraction; 3) too many definitions and theorems to be studied so that students are confused in determining 
which definitions or theorems should be used to work on and prove abstraction on the given problem.

The researchers conducted a study based on the perspective of learning theory that has been formulated by experts who adapted to the characteristics of skills and habits of learning and thinking students semester V academic year 2016/2017 mathematics education FKIP UNSUR. Given the characteristics of students who have started to work (honorary teachers) and active in various activities and student organizations that nota bene can not set the time betwen lectures with other activities, then most of the student activities are busy by other activities besides study so that the time of study and student independence In learning is very limited. In addition, the abstract characteristics of algebra structure II material also require the lecturer's dominance in delivering the material in the lecture.

Based on the above allegations and assessments, in formulating interventions to overcome the problems that occur, researchers are guided by the theory of learning behaviorism and constructivism, including the theory of reinforcement of bf Skinner, Pavlov's conditioning theory, and social interaction learning theory from Vygotsky who emphasizes the giving of scaffolding, the theory of metacognition that emphasizes the learner the ability to look at yourself so that what he did can be controlled optimally. the interventions that can be formulated from the results of the research that has been done by researchers are: 1) provide reinforcement to the mastery of prerequisite material, 2) perform conditioning through drill, practice, and exercise, and 3) provide scaffolding in the form of deductive proof instructions by including definitions or theorems for thinking of mathematical abstractions; 4) raises students awareness of what they learn (metacognition), 5) convergent interventions in the form of a closed-ended investigative question and leads to problem solving given at the beginning of the lesson, as students look for patterns and generalize concepts; and 6) devise a didactic design, which takes into account the characteristics and nature of the concept.

Some studies of abstraction abilities that have been done before are still theoretical (Ferarri, 2003; Goodson-Espy, 2005). It means that the study is still a description of the emergence of theories and critiques about the abstraction not yet on the stage of learning in the classroom. In addition, research that has been studied by Dindyal (2007) reveals that abstraction is done on the topic of geometry. Also in line with the research (Dindyal, 2007) separately undertook intensive abstraction research, using a quantitative approach to examine the abstraction process in Junior High School students. So that researcher do research about bastraksi ability in material of Algebra Structure which done by student by using megasar approach disursif integration of peer instruction.

\section{CONCLUSION}

Based on results and discussion, then the conclusion of the results of this study is (1) The ability of students' mathematical abstraction using the discursive approach of peer instruction integration in the course of algebra structure II does not exceed $85 \%$ of ideal criteria set; (2) Problems faced by students in performing mathematical abstraction commonly called obstacles including the cognitive obstacles, occurs when students have difficulty in the learning process; genetic and psychological obstacles occur as a result of a student's personal development; didactic obstacles, occur because of the nature of teaching from the teacher; epistemological obstacles occur because of the nature of the mathematical concepts themselves; (3) Interventions that need to be given to the students to overcome the problems such as by providing reinforcement to the mastery of prerequisite material, conditioning 
through drill, practice, and exercise, providing scaffolding in the form of abstraction instructions by including the definition or theorems for mathematical abstraction, raises students' awareness of what they learn (metacognition), convergent interventions in the form of a closed-ended investigative question and leads to problem solving given at the beginning of the lesson, as students look for patterns and generalize concepts and design didactic, which takes into account the characteristics and properties of the concept.

\section{ACKNOWLEDGMENTS}

Thus the author can convey the results of research contained in this article. On this occasion, the authors would like to express the appreciation and gratitude to all the parties that have the big impact on the success and completion of this research. The author realized that this article is far from perfect, therefore constructive criticism and suggestions are desirable for the perfection of this article. Hopefully, this research will be useful for the reader.

\section{REFERENCES}

Anderson, T., Howe, C., Soden, R., Halliday, J., \& Low, J. (2001). Peer interaction and the learning of critical thinking skills in further education students. Instructional Science, 29(1), 1-32.

Artigue, M. (1998). Teacher training as a key issue for the integration of computer technologies. In Information and communications technologies in school mathematics (pp. 121-129). Springer, Boston, MA.

Bermejo, V., \& Díaz, J. J. (2007). The degree of abstraction in solving addition and subtraction problems. The Spanish journal of psychology, 10(2), 285-293.

Crouch, C. H., \& Mazur, E. (2001). Peer instruction: Ten years of experience and results. American journal of physics, 69(9), 970-977..

Dindyal, J. (2007). High school students' use of patterns and generalisations. Proceedings of the 30th Annual Conferences of the Mathematics Education Research Group of Australasia, 1(July), 236-245.

Fagen, A. P., Crouch, C. H., \& Mazur, E. (2002). Peer instruction: Results from a range of classrooms. The physics teacher, 40(4), 206-209..

Ferrari, P. L. (2003). Abstraction in mathematics. Philosophical Transactions of the Royal Society of London B: Biological Sciences, 358(1435), 1225-1230.

Goodson-Espy, T. (2005). Why reflective abstraction remains relevant in mathematics education research. In Proceedings of the 27th Annual Meeting of the North American Chapter of the International Group for the Psychology of Mathematics Education, Roanoke, VA. Retrieved from http://www. pmena. org/2005/PMENA_2005_Proceedings. pdf.

Herlina, E. (2015). Meningkatkan advanced mathematical thinking mahasiswa. Infinity Journal, 4(1), 65-83.

Mitchelmore, M., \& White, P. (2007). Abstraction in Mathematics Learning. Mathematics Education Research Journal, 19(2), 1-9.

Nicol, D. J., \& Boyle, J. T. (2003). Peer instruction versus class-wide discussion in large classes: a comparison of two interaction methods in the wired classroom. Studies in higher education, 28(4), 457-473. 
34 Komala, Analysis of Students' Mathematical Abstraction Ability ...

Nurhasanah, F., Kusumah, Y. S., \& Sabandar, J. (2017). Concept of triangle: Examples of mathematical abstraction in two different contexts. International Journal on Emerging Mathematics Education, 1(1), 53-70.

Nurlaelah, E., \& Sumarmo, U. (2009). Implementasi Model Pembelajaran Apos dan Modifikasi-APOS (M-APOS) pada Matakuliah StrukturAljabar.

Tall, D. (2008). The transition to formal thinking in mathematics. Mathematics Education Research Journal, 20(2), 5-24.. 